EISSN: 2706-7955 ISSN: 2077-4605

DOI: $10.36632 /$ mejar/2021.10.4.89

Journal homepage: www.curresweb.com

Pages: 1310-1318

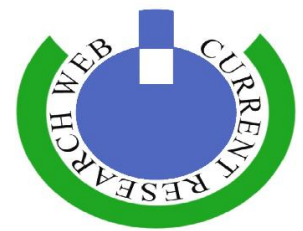

\title{
Phenolic Content of Dill Seed Extracts as Antifungal Agent against Aspergillus spp.
}

\section{Sara E. Gomaa ${ }^{1}$ and Emad El Din G. Gomaa ${ }^{2}$}

${ }^{1}$ Medicinal and Aromatic plants Research Department, Horticulture Research Institute (HRI), Agriculture Research Center (ARC), Giza, Egypt.

${ }^{2}$ Food Science and Technology Department, Faculty of Agriculture, Alexandria University, Alexandria, Egypt.
Received: 20 Oct. 2021
Accepted: 25 Nov. 2021
Published: 10 Dec. 2021

\begin{abstract}
This study was performed to examine the effect of phenolic compounds and antioxidant content of four dill seed extracts. These extracts were prepared by hydro-distillation, ethanol, methanol and acetone. They were examined as antifungal agent against eight Aspergillus spp. Results revealed that hydrodistillation extract (HE) and ethanol extract (EE), derived from dill seed, had higher total phenolic content (45.67 and 39.71 GAE/g, respectively), as well as higher contents of butylated hydroxyanisole (BHA), butylated hydroxytoluene (BHT) and octyl methylcinnamate (OMC) $(4.98,1.50,39.65$ and $4.37,1.10,33.26 \mathrm{mg} / \mathrm{ml}$, respectively) as compared to the methanol and acetone extracts. HE recorded a high diameter of inhibition zone (DIZ) with A. flavus IFO 6343, A. niger DSM 371 and A. parasciticus $N R R L$ 2999, with MIC $=15 \mathrm{mg} / 1$. While EE was more effective on A. niger CAIM 147, A. niger NRRL 337 and $A$. oryzae NRRL 9362, with MIC $=15 \mathrm{mg} / \mathrm{l}$ as compared with methanol and acetone extracts under the same conditions. Antifungal potential of HE and EE were found to be highly effective on enumeration of fungal strains used in this study. Obtained results confirmed strong relationship between the total phenolic content of dill seed extracts and its amounts of BHA as an antifungal agent. It is recommended to use dill HE (light yellow color) with foods highly expected to be infected with $A$. flavus IFO 6343, A. niger DSM 371 and A. parasciticus NRRL 2999, at 15 and $20 \mathrm{mg} / 1$, while EE (pale yellow color) is recommended to prevent foods to be susceptible to A. niger CAIM 147, A. niger NRRL 337 and $A$. oryzae NRRL 9362 at 15 and $20 \mathrm{mg} / \mathrm{l}$.
\end{abstract}

Keywords: Dill seed extracts, hydro-distillation, Ethanol, methanol, acetone, Aspergillus spp., phenolic compounds, antioxidants.

\section{Introduction}

Dill plant (Anethum graveolens) is an important member of the Umbelliferae family, which is native to southwest Asia, southeast Europe and also the Mediterranean region (Tian et al., 2012 and Nada et al., 2018). It grows in many countries such as Iran, India, Russia and Egypt (Noah et al., 2017). It is known in Egypt as Shapt (Dahiya and Purkayastha, 2012) and has been used as an aromatic, medicinal and culinary herb since early decades (Hojjati, 2017). Compounds from aromatic plants have been recognized as a natural source for antibacterial and antifungal properties since early time in several countries. They are rich source of essential oils (EO) as it contains several biologically active ingredients used as antimicrobial agents (Hussein et al., 2015 and Nguyen et al., 2020) as well as flavoring agents in food and beverages (Najaran et al., 2016). Essential oil containing bioactive phenolic and antioxidant compounds are often gained by hydro-distillation or extracted by some organic solvents from the whole plant or different parts i.e. leaves, stems or even their seeds (Tongnuanchan and Benjakul, 2014). Moreover, these extracts might have antimicrobial effect (Delaquis et al., 2002 and Arora and Kaur 2007). Different experimental techniques have been used to explain the antimicrobial

Corresponding Author: Sara E. Gomaa, Medicinal and Aromatic plants Research Department, Horticulture Research Institute (HRI), Agriculture Research Center (ARC), Giza, Egypt.

E-mail: sara_gomaa@hotmail.com 
characteristics and the chemical composition of these essential oils (Delaquis et al., 2002, AlMa'adhedi, 2012, Taota et al., 2016 and Nada et al., 2018).

Essential oils of dill seeds have more than 40 constituents, which could be identified as essential volatiles and when tested as an antimicrobial agent, it showed a high activity against Aspergillus niger, Saccaromyces cerevisiae and Candida albicans (Jirovetz et al., 2003 and Nehdia et al., 2020). Dill seed oil consists of $\alpha$-phellandrene, eugenol, anethole, flavonoids, coumarine, triterpenes and phenolic acid (Jana and Shekhawat, 2010 and Said-Al Ahl and Omer, 2016). EO chemical composition differs according to the plant part, developing stage and also the extraction method (Singh et al., 2006 and $\mathrm{Al}$ Ma'adhedi 2012). Volatile oil obtained from dill seed hydro-distillation and acetone extraction was found to have an inhibition effect on the fungal mycelial growth as, inhibition zone increased with the volatile oil dose, where, it completely inhibited Fusarium graminearum growth, followed by $F$. citrinum, Aspergillus flavus and A. terreus (Singh et al., 2006 and Prakash et al., 2012).

Aspergillus is a filamentous fungus, with more than 185 identified species worldwide. More than 20 species of which were reported to cause harmful infection in humans, animals and plants (Cleveland et al., 2009). A. flavus and A. parasiticus are the most harmful species due to their direct infection and toxification to human kind (Tian et al., 2012 and Noah et al., 2017). They are mainly concerned with food poisoning as they play a main role in aflatoxins production which are involved in food contamination and toxification (Kumar et al., 2017). They also affect plant metabolism by altering with vital cellular enzymes, pigmentation and decrease germination ability (Alpsoy, 2010). Polyphenols concentration and microbial enzymes activity are related, as polyphenols can interfere with cell membrane specific sites to interact with microbial membrane proteins, enzymes and lipids, and alter their cell permeability to permit protons, ions and macromolecules loss (Taotao et al., 2016). This cellular components loss cause deformation in cell structure and consequently led to inhibition of the cellular growth (Bajpai et al., 2013). Phenolic antioxidants i.e. butylated hydroxyanisole (BHA), butylated hydroxytoluene (BHT) and tertiary butyl-hydroquinone (TBHQ) are classified as phenols that have antimicrobial activity, against gram positive and negative bacteria as well as molds and yeasts (Suh et al., 2005). It was reported that, those phenolic antioxidants belong to some compounds that retard oxidation such as BHA, BHT, tert-butylhydroquinone (TBHQ) and propyl gallate (PG) (Shahidi and Ambigaipalan, 2015). Some scientists had observed that these compounds had an excellent effect against a wide range of microorganisms (Razavi-Rohani and Griffiths, 1999 and Arroyo, 2003) such as viruses, protozoa, bacteria, yeast and molds growth (Swamy et al., 2016). From the previous four phenolic antioxidants, both BHA and Polypropylene (PP) showed the highest antimicrobial activity in vitro (Arroyo, 2003).

The objective of this study was to determine the phenolic and antioxidant compounds content of four dill seed extracts, as well as the antifungal evaluation of these extracts against eight Aspergillus strains.

\section{Materials and Methods}

\subsection{Plant Material Source:}

Dill (Anethum graveolens L.) seeds -GoldKrone- were purchased from Enza Zaden, Netherlands. Seeds were selected carefully to remove bad ones, washed well with running water for 30 minutes, dried and then grinded. Extraction was done by hydro-distillation and by three other solvents (ethanol, methanol and acetone).

\subsection{Dill Seed Extraction Method:}

Hydro-distillation was performed using Clevenger type apparatus for three hours as recommended by Asadipour et al. (2003), while extraction by solvents, were done using ethanol, methanol and acetone (El-Gomhouria Co., for Trading pharmaceutical, chemicals and medical appliance, Alexandria governorate, Egypt) according to Gomaa et al. (2016). Fifteen grams of grinded dill seeds were added to $300 \mathrm{ml}$ of each solvent individually, for 12 hours under shaking at room temperature then filtrated. After then, solvents were evaporated using rotary evaporator (Yamato Scientific Ltd., Japan; using pump, JEIO TECH, VE-11, Korea) at $40^{\circ} \mathrm{C}$ until dryness. Extracts were stored in dark sealed glass bottles at $4^{\circ} \mathrm{C}$ until used (Gomaa and Abdel Rahman, 2013). 


\subsection{Total Phenolic Content:}

Total phenolic content were determined by The Folin Ciocalteu reagent (FCR), also called the gallic acid equivalence method (GAE), as mentioned by Singleton and Rossi (1965). Ultravioletvisible (UV-Vis) spectrophotometry (Thermo electron corporation- Korea) was used. The total phenolic content was expressed as milligram of Gallic acid equivalent per gram of dill seeds dry weight (mg GAE/g).

\subsection{Phenolic and Antioxidants Compounds Extraction:}

Butylated hydroxyanisole (BHA), butylated hydroxytoluene (BHT) and octyl methylcinnamate (OMC); were determined as described by Akkbik et al. (2013); $0.5 \mathrm{~g}$ of extract sample were added to $25 \mathrm{ml} \mathrm{n}$-hexane; followed by $25 \mathrm{ml}$ of acetonitrile, followed by refluxing for $30 \mathrm{mins}$ at $70^{\circ} \mathrm{C}$ with stirring. After that, crude extract was transferred to a separator funnel to separate n-hexan from acetonitrile. The later was concentrated using a vacuum rotary evaporator at $45^{\circ} \mathrm{C}$, then the residue was re-dissolved in $10 \mathrm{ml}$ of acetonitrile, filtered and diluted to $25 \mathrm{ml}$ with acetonitrile. Stock solution was stored in dark place at $4^{\circ} \mathrm{C}$ until use. Acetonitrile, n-hexane and acetic acid. D-gallic acid standards of BHA, BHT and OMC were supplied from Sigma-Aldrich (St. Louis, USA). Quantitative and qualitative analysis of each BHA, BHT and OMC were performed by Shimadzer HPLC (model: LC-20AT equipped with four pumps and Shimadzu SPD-20 AV UV/Vis) detector using 50 $\mu$ l of each samples. HPLC analysis condition was modified from Saad et al. (2007) using $280 \mathrm{~nm}$ as maximum wave length with mobile phase; acetonitrile and (water: acetic acid 99:1/v/v) and flow rate of $0.8 \mathrm{ml} / \mathrm{min}$. Average concentration of phenolic antioxidants BHA, BHT and OMC were expressed by milligram per gram $(\mathrm{mg} / \mathrm{g})$.

\subsection{Aspergillus Strains:}

Eight culture strains of Aspergillus spp., were used in the present study, illustrated as follows:

\begin{tabular}{|c|c|c|c|c|}
\hline & Code & Strain name & Source & Origin \\
\hline 1 & Afla I & A. flavus AТCC 16875 & The American Type Culture Collection (ATCC). & USA \\
\hline 2 & Afla II & A. flavus IFO 6343 & $\begin{array}{l}\text { Institute for Fermentation, Osaka (IFO). } \\
\text { Cairo Mircen Culture Collection Microbiology }\end{array}$ & Japan \\
\hline 3 & Aniger I & A. niger CAIM 157 & $\begin{array}{l}\text { Resource Center- Ain Shams University } \\
\text { (CAIM). }\end{array}$ & Egypt \\
\hline 4 & Aniger II & A. niger DSM 731 & $\begin{array}{l}\text { German Collection of Microorganisms and Cell } \\
\text { Cultures GmbH, Deutsche Sammlung von } \\
\text { Mikroorganismen GmbH (DSM) }\end{array}$ & Germany \\
\hline 5 & Aniger III & A. niger NRRL 337 & $\begin{array}{l}\text { Northern Regional Research Laboratory } \\
\text { (NRRL). }\end{array}$ & USA \\
\hline 6 & Aoryz. & A. oryzae NRRL 9362 & $\begin{array}{l}\text { Northern Regional Research Laboratory } \\
\text { (NRRL). }\end{array}$ & USA \\
\hline 7 & Aparast. & A. parasiticus NRRL 2999 & $\begin{array}{l}\text { Northern Regional Research Laboratory } \\
\text { (NRRL). }\end{array}$ & USA \\
\hline 8 & Aphoen. & A. phoenicis CAIM 149 & $\begin{array}{l}\text { Cairo Mircen Culture Collection Microbiology } \\
\text { Resource Center- Ain Shams University } \\
\text { (CAIM). }\end{array}$ & Egypt \\
\hline
\end{tabular}

Aspergillus strains were cultured in Potato dextrose agar (PDA) and incubated at $32{ }^{\circ} \mathrm{C}$ for 7 days until complete sporulation as mentioned by Difco Manual (1984).

\subsection{Essential oil (EO) Effect against Aspergillus spp.:}

Diluted spores' suspensions of the eight fungal strains were prepared by adding $10 \mathrm{ml}$ of $0.1 \%$ sterilized peptone water. Spores enumeration was made by cell count indirect technique (De Moss and Bard, 1957). Disc-diffusion method was used for diameter of inhibition zone (DIZ mm) determination with different dill seed extracts as suggested by Efstration et al. (2012). One $\mathrm{ml}$ of each fungal suspension was added to $10 \mathrm{ml}$ of PDA medium $\left(45-50^{\circ} \mathrm{C}\right)$ and poured into petri dishes. After media solidification, sterilized filter paper discs ( $4 \mathrm{~mm}$ in diameter) were put on the surface of inoculated media, then injected with $10 \mathrm{mg} / 1$ of dill extract to be tested, while $10 \%$ dimethyl sulfoxide (DMSO) was used as a negative control (Abd-Alla et al., 2013 and Gomaa et al., 2016). Clotrimazole (1\% w/w) was used as a positive control as recommended by Villanueva et al. (2008) and Madugula et al. (2017). 
Plates were incubated for 48 hours at $28{ }^{\circ} \mathrm{C}$. The antifungal activity was measured as diameter of inhibition zone (DIZ) in $\mathrm{mm}$ around filter paper disc. This experiment was repeated in triplets.

The most effective extracts were selected to find the minimum inhibitory concentration (MIC) using serial dilutions $(5,10,15,20,30 \mathrm{mg} / \mathrm{l})$. Aspergillus strains under this study were added to sterilized PDA media along with $1 \mathrm{ml}$ of each Aspergillus strain spore suspension (in $0.1 \%$ peptone water) and incubated for 48 hours at $28^{\circ} \mathrm{C}$. Then, MIC values were determined as the lowest antifungal concentration that inhibited visible growth of tested Aspergillus strains. Each test was performed in triplets.

\subsection{Statistical analysis:}

Data were performed using Costat software (version 6.400) as one-way randomized complete design (RCD). Comparisons among the means of different treatments were done using the least significant differences (L.S.D) test procedure at $\mathrm{p} \leq 0.05$ level of probability, as illustrated by Snedecor and Cochran (1980).

\section{Results and Discussion}

The present study was conducted to examine the antifungal effect of dill seed EO extracted by hydro-distillation, ethanol, methanol and acetone against eight Aspergillus strains.

Dill seed extract obtained by hydro-distillation, was light yellow color. While the color of ethanol, methanol and acetone extracts were pale-yellow. Color of the extract is very important factor and essential when adding these extracts to foods for the purpose of preservation. These results came in agreement with Dahiya and Purkayasthat (2012), who stated that volatile essential oil of dill seeds, has light yellow color. Also, Singh et al. (2006) and Al-Ma'adhedi (2012) stated that, dill seed oil has a pale yellow color. They also reported that, dill seed oil amount varies depending on the extraction method.

Essential oils yield obtained from dill seeds by different extraction methods are presented in Table (1). Data showed that, hydro-distillation extract yield was $2.2 \%$, while ethanol extract (EE) yield was $2.5 \%$ with no significant difference between them. Methanol extract (ME) and acetone extract (AE) yields were 1.3 and $1.8 \%$ respectively. Total phenolic content (mg GAE/g) showed in Table (1) significantly gave the highest content by $\mathrm{HE}(45.67 \mathrm{mg} \mathrm{GAE} / \mathrm{g})$. EE possessed $39.71 \mathrm{mg} \mathrm{GAE} / \mathrm{g}$ followed by ME and $\mathrm{AE}$ (27.40 and $25.50 \mathrm{mg} \mathrm{GAE} / \mathrm{g}$, respectively).

Table 1: Total phenolic yield and content of different dill seed extracts.

\begin{tabular}{|c|c|c|}
\hline Extract & Total phenolic yield (\%) & Total phenolic content (mg GAE/g) \\
\hline HE & $2.20 \pm 0.30^{\mathrm{a}}$ & $45.67 \quad \pm 0.19^{\mathrm{a}}$ \\
\hline $\mathbf{E E}$ & $\pm 0.21^{\mathrm{a}}$ & $39.71 \pm 0.29^{b}$ \\
\hline ME & $\pm 0.10^{\mathrm{c}}$ & $27.40 \pm 0.30^{c}$ \\
\hline $\mathbf{A E}$ & $\pm 0.17^{\mathrm{b}}$ & $\pm 0.26^{\mathrm{d}}$ \\
\hline
\end{tabular}

Mean \pm standard deviation of triplicate determined in dry weight basis.

HE: Hydro-distillation extract, EE: Ethanol extract, ME: Methanol extract, AE: Acetone extract.

Means within a column followed by the same letter are not significantly different according to LSD test at $\mathrm{p} \leq 0.05$.

Concerning antioxidant phenolic compounds shown in Table (2), HE significantly had higher content of BHA, BHT and OMC $(4.98,1.50,39.65 \mathrm{mg} / \mathrm{g}$, respectively) as compared with other tested solvents. EE came in the second place in this respect as it recorded 4.37, 1.10 and $33.26 \mathrm{mg} / \mathrm{g}$, regarding BHA, BHT and OMC contents, while ME and AE recorded $(3.09,0.71,32.80)$ and $(2.89,0.75,20.42)$ $\mathrm{mg} / \mathrm{g}$, respectively. Generally, $\mathrm{ME}$ and AE significantly possessed lower values for the phenolic compounds as compared with $\mathrm{HE}$ and EE extracts. These results came in agreement with Singh et al. (2006) who found that dill seed extraction by hydro-distillation in a Clevenger type apparatus for 6 hours was $2.6 \%$, while the yield was $1.8 \%$ when extracted by acetone at Soxhlet apparatus for 5 hours. Also this was supported by Stanojevic et al. (2015) who mentioned that hydro-distillation of dill seeds yielded $2.8 \mathrm{ml} / 100 \mathrm{~g}$ dry weight. 
Table (3) shows the antifungal assay conducted by the disc diffusion method for measuring the diameter of inhibition zone (DIZ) of Aspergillus spp. using $10 \mathrm{mg} / 1$ of the extracted oils. Results obtained from this study showed that dill seed extracts were effective on all tested Aspergillus strains. HE significantly had the highest inhibitory effect on Afla II, Aniger II and Aparast as they recorded DIZ of 18.33, 20.67 and $19.67 \mathrm{~mm}$, respectively; with a significant difference from the commercial positive control (Clotrimazole). Also, data showed that EE extract significantly gave the highest DIZ against Aniger I, Aniger III and Aoryz strains (20.33, 20.67 and $20.00 \mathrm{~mm}$, respectively). As for Afla I and Aphoen strains, Clotrimazole (positive control) significantly gave the highest DIZ (18.00 and 15.67 $\mathrm{mm}$, respectively) followed by HE with DIZ 11.00 and $10.00 \mathrm{~mm}$ for the previous mentioned strains, respectively. Clotrimazole, generally had a higher significant DIZ than ME and AE at all Aspergillus spp. under study.

Table 2: Average concentration $(\mathrm{mg} / \mathrm{g})$ of phenolic compounds in different dill seed extracts.

\begin{tabular}{|c|c|c|c|c|c|c|}
\hline \multirow{2}{*}{$\frac{\text { Extract }}{\text { HE }}$} & \multicolumn{2}{|c|}{ BHA } & \multicolumn{2}{|c|}{ BHT } & \multicolumn{2}{|c|}{ OMC } \\
\hline & 4.98 & $\pm 0.49^{\mathrm{a}}$ & 1.50 & $\pm 0.20^{\mathrm{a}}$ & 39.65 & $\pm 0.05^{\mathrm{a}}$ \\
\hline $\mathbf{E E}$ & 4.37 & $\pm 0.28^{b}$ & 1.10 & $\pm 0.10^{\mathrm{b}}$ & 33.26 & $\pm 0.17^{\mathrm{b}}$ \\
\hline ME & 3.09 & $\pm 0.05^{\mathrm{c}}$ & 0.71 & $\pm 0.09^{\mathrm{c}}$ & 32.80 & $\pm 0.78^{\mathrm{c}}$ \\
\hline $\mathbf{A E}$ & 2.89 & $\pm 0.28^{\mathrm{c}}$ & 0.75 & $\pm 0.22^{\mathrm{bc}}$ & 20.42 & $\pm 0.18^{\mathrm{d}}$ \\
\hline
\end{tabular}

Mean \pm standard deviation of triplicate determined in dry weight basis.

HE: Hydro-distillation extract, EE: Ethanol extract, ME: Methanol extract, AE: Acetone extract.

Means within a column followed by the same letter are not significantly different according to LSD test at $\mathrm{p} \leq 0.05$.

Table 3: Diameter of Inhibition zone (DIZ)* of extracted EO of dill seeds (10mg/L) against tested Aspergillus strains growth.

\begin{tabular}{|c|c|c|c|c|c|}
\hline HE & $\mathbf{E E}$ & ME & $\mathbf{A E}$ & DMSO & Clotrimazole \\
\hline \multicolumn{6}{|c|}{ Afla I (A. flavus ATCC 16875) } \\
\hline $11.00^{\mathrm{b}}$ & $8.33^{\mathrm{c}}$ & $8.00^{\mathrm{c}}$ & $8.33^{c}$ & $0.00^{\mathrm{d}}$ & $18.00^{\mathrm{a}}$ \\
\hline \multicolumn{6}{|c|}{ Afla II (A. flavus IFO 6343) } \\
\hline $18.33^{\mathrm{a}}$ & $12.00^{\mathrm{c}}$ & $11.00^{\mathrm{cd}}$ & $9.67^{\mathrm{d}}$ & $0.00^{\mathrm{e}}$ & $15.00^{\mathrm{b}}$ \\
\hline \multicolumn{6}{|c|}{ Aniger I (A. niger CAIM 147) } \\
\hline $12.33^{\mathrm{c}}$ & $20.33^{\mathrm{a}}$ & $10.00^{\mathrm{d}}$ & $11.33^{\mathrm{cd}}$ & $0.00^{\mathrm{e}}$ & $16.67^{\mathrm{b}}$ \\
\hline \multicolumn{6}{|c|}{ Aniger II (A. niger DSM 731) } \\
\hline $20.67^{\mathrm{a}}$ & $11.33^{\mathrm{c}}$ & $10.67^{\mathrm{c}}$ & $11.33^{c}$ & $0.00^{\mathrm{d}}$ & $18.00^{\mathrm{b}}$ \\
\hline \multicolumn{6}{|c|}{ Aniger III (A. niger NRRL 337) } \\
\hline $11.33^{\mathrm{c}}$ & $20.67^{\mathrm{a}}$ & $7.67^{\mathrm{d}}$ & $6.00^{\mathrm{e}}$ & $0.00^{\mathrm{f}}$ & $16.33^{\mathrm{b}}$ \\
\hline \multicolumn{6}{|c|}{ Aoryz. (A. oryzae NRRL 9362) } \\
\hline $12.00^{\mathrm{c}}$ & $20.00^{\mathrm{a}}$ & $8.00^{\mathrm{e}}$ & $10.00^{\mathrm{d}}$ & $0.00^{\mathrm{f}}$ & $15.67^{\mathrm{b}}$ \\
\hline \multicolumn{6}{|c|}{ Aparast. (A. parasiticus NRRL 2999) } \\
\hline $19.67^{\mathrm{a}}$ & $12.00^{\mathrm{c}}$ & $7.67^{\mathrm{d}}$ & $7.66 \mathrm{~d}$ & $0.00^{\mathrm{e}}$ & $15.67^{\mathrm{b}}$ \\
\hline \multicolumn{6}{|c|}{ Aphoen. (A. phoenicis CAIM 149) } \\
\hline $10.00^{\mathrm{b}}$ & $8.67^{c}$ & $7.67^{\mathrm{c}}$ & $5.00^{\mathrm{d}}$ & $0.00^{\mathrm{d}}$ & $15.67^{\mathrm{a}}$ \\
\hline
\end{tabular}

*Mean of Diameter of inhibition zone (DIZ) in mm, including disc paper diameter of $4 \mathrm{~mm}$.

HE: Hydro-distillation extract, EE: Ethanol extract, ME: Methanol extract, AE: Acetone extract.

DMSO: Dimethyl sulfoxide, Clotrimazole: commercial positive control.

Means within the same row followed by the same letter are not significantly different according to LSD test at $\mathrm{p} \leq 0.05$.

This was supported by El-Gayyar et al (2001) who found that DIZ for A. niger was $12 \mathrm{~mm}$ with $24 \mathrm{mg}$ of dill seed extract by hydro-distillation. Also, Singh et al (2006) found that DIZ of EE were $100 \%$ and $82.5 \%$ against both of $A$. niger and A. flavus, respectively, while AE gave 42.3 and $56.5 \%$ effectiveness, respectively. These results came in agreement with Nada et al. (2018) who observed that HE gave DIZ results against, $A$. flavus, A. niger, Pencillium expensum and $P$. islandicum, by 70, 60, 34 and $33 \mathrm{~mm}$ respectively. Consequently, dill seed extracts can be considered a potential source of antifungal growth, as its EO has the ability to inhibit Fusarium species through damaging cytoplasm and cellular constituents as well as distortion of mycelia (Taotao et al., 2016 and Mani-López et al., 2021). 
According to the previous results illustrated in Table (3), HE was the most effective against Afla II, Aniger II and Aparast. Also, EE affected Aniger I, Aniger III and Aoryz. Accordingly those 2 extracts were selected to be tested against the above mentioned Aspergillus strains with serial dilutions.

Results of HE serial dilutions in Table (4) showed that, total count of Afla II, Aniger II and Aparast. were inversely proportional to the extract concentration. Viable count of $A$. nigerII was reduced by $1 / 3$ initial inoculum count $\left(322 \times 10^{4} \mathrm{CFU} / \mathrm{ml}\right)$ when using $5 \mathrm{mg} / 1$ of the extract, while at $10 \mathrm{mg} / \mathrm{l}$, the total viable count recorded $5 \times 10^{4} \mathrm{CFU} / \mathrm{ml}$ and no growth was recorded at higher concentrations. On the other hand using $(15 \mathrm{mg} / \mathrm{l})$ extract decreased the total count of Afla II and Aparast. from initial inoculum $\left(250 \times 10^{4}\right)$ to $\left(11 \times 10^{4} \mathrm{CFU} / \mathrm{ml}\right)$ and from $\left(266 \times 10^{4}\right)$ to $\left(18 \times 10^{4}\right)$ $\mathrm{CFU} / \mathrm{ml}$, respectively. And at $20 \mathrm{mg} / \mathrm{l}$, HE inhibited fungal growth completely. Accordingly to the previous data revealed in Table (4), growth of Aniger II was totally inhibited at $15 \mathrm{mg} / \mathrm{l}$ of HE while $A$ fla II and Aparast. growth was totally inhibited at $20 \mathrm{mg} / \mathrm{l}$ concentration.

Table 4: Fungal count* of MIC** values using HE (mg/l) against the three Aspergillus selected strains.

\begin{tabular}{ccccccc}
\hline Aspergillus strains & $\mathbf{0}$ & $\mathbf{5}$ & $\mathbf{1 0}$ & $\mathbf{1 5}$ & $\mathbf{2 0}$ & $\mathbf{3 0}$ \\
\hline Afla $\boldsymbol{I I}$ & $250 \times 10^{4}$ & $192 \times 10^{4}$ & $87 \times 10^{4}$ & $11 \times 10^{4}$ & 0 & 0 \\
\hline Aniger $\boldsymbol{I I}$ & $322 \times 10^{4}$ & $110 \times 10^{4}$ & $5 \times 10^{4}$ & 0 & 0 & 0 \\
\hline Aparast. & $266 \times 10^{4}$ & $180 \times 10^{4}$ & $90 \times 10^{4}$ & $18 \times 10^{4}$ & 0 & 0 \\
\hline
\end{tabular}

* Fungal count: $\mathrm{CFU} / \mathrm{ml}$

**MIC: the minimum inhibitory concentration

Concerning EE serial dilutions illustrated in Table (5), results indicated $15 \mathrm{mg} / \mathrm{l}$ stopped totally AnigerI growth. Aoryz. count decreased from $273 \times 10^{4} \mathrm{CFU} / \mathrm{ml}$ at $5 \mathrm{mg} / 1$ to $12 \times 10^{4} \mathrm{CFU} / \mathrm{ml}$ at 15 $\mathrm{mg} / \mathrm{l}$ of EE, while at $20 \mathrm{mg} / \mathrm{l}$ no growth was noticed. Same results were obtained Aniger III at $15 \mathrm{mg} / \mathrm{l}$ as total viable count of initial inoculum was reduced from $392 \times 10^{4} \mathrm{CFU} / \mathrm{ml}$ to $4 \times 10^{4} \mathrm{CFU} / \mathrm{ml}$. But no growth was observed at $20 \mathrm{mg} / \mathrm{l}$ by the same dill seed oil. Accordingly, MIC of EE was $15 \mathrm{mg} / \mathrm{l}$ for Aniger I, while it was $20 \mathrm{mg} / 1$ for both Aniger III and Aoryz.

Table 5: Fungal count* of MIC** values using EE (mg/l) against the three Aspergillus selected strains.

\begin{tabular}{ccccccc}
\hline Aspergillus strains & $\mathbf{0}$ & $\mathbf{5}$ & $\mathbf{1 0}$ & $\mathbf{1 5}$ & $\mathbf{2 0}$ & $\mathbf{3 0}$ \\
\hline Aniger I & $415 \times 10^{4}$ & $362 \times 10^{4}$ & $17 \times 10^{4}$ & 0 & 0 & 0 \\
\hline AnigerIII & $392 \times 10^{4}$ & $214 \times 10^{4}$ & $19 \times 10^{4}$ & $4 \times 10^{4}$ & 0 & 0 \\
\hline Aoryz. & $390 \times 10^{4}$ & $273 \times 10^{4}$ & $52 \times 10^{4}$ & $12 \times 10^{4}$ & 0 & 0 \\
\hline
\end{tabular}

* Fungal count: $\mathrm{CFU} / \mathrm{ml}$

**MIC: the minimum inhibitory concentration

Results were supported by Tian et al. (2012) who observed that dill seed extracts have ability to disrupt permeability barrier of plasma membrane of fungi and can cause morphological change in the cell. Again, Ghadimipour and Eveghad (2015) proved that, the BHA has an important role as antifungal agent in culture media. Taotao et al. (2016) stated the BHA can cause cytoplasm and cellular constituents leaking and destroy the fungal mycelia. Fung et al. (1977) stated that BHA had an inhibitory effect on growth and toxicity of six Aspergillus flavus of non-toxigenic strains, while BHT at the same concentration had no visible inhibitory effect. Also as a result Raccach (1984) reported that inhibition mechanism of bacteria, yeasts and molds growth by phenolic antioxidants has been found to affect the cellular membrane function and composition as well as the synthesis of DNA, RNA, protein, lipid, and the function of the mitochondria, these effects were also supported by Ilhami et al. (2004) who confirmed that the inhibitory powers of BHA are due to disruption of cytoplasmic membrane of microbial cell, also phenolic compounds may function as a membrane perturbed which is inserted between lipid layer of the microbial cell, causing disruption of ordered state of the alkyl chains.

\section{Conclusion}

It is recommended to use dill $\mathrm{HE}$ (light yellow color) with foods highly expected to be infected with to A. flavus IFO 6343, A. niger DSM 731 and A. parasiticus NRRL 2999 at 15 and $20 \mathrm{mg} / \mathrm{l}$, while dill EE (pale yellow color) is recommended to be used with foods to prevent food from contamination with A. niger CAIM 147, A. niger NRRL 337 and A. oryzae NRRL 9362 at 15 and $20 \mathrm{mg} / \mathrm{l}$. 


\section{References}

Abd-Alla, A.A., C.Y. Ishak and S.M.H. Ayoub, 2013. Antimicrobial activity of four medicinal plants used by Sudanese traditional medicine. J Forest Prod Indust., 2(1): 29-33.

Akkbik, M., Z. B. Assim, and F. B. Ahmad, 2013. Optimization and Validation of RP-HPLC-UV/Vis Method for Determination Phenolic Compounds in Several Personal Care Products. Hindawi Publishing Corporation International, J. of Analytical Chem., 8(2): 78-89. doi:10.1155/2011/858153.

Al-Ma'adhedi, S. H. F., 2012. Phytochemical Screening, Estimation of Some Heavy Metals Concentrations, and Specific Extraction of Bioactive Components from Iraqi Anethum graveolens L. Seeds and Studying their Antibacterial. Al-Anbar J of Veterinary Sci., 5(2): 28-36.

Alpsoy, L., 2010. Inhibitory effect of essential oil on aflatoxin activities. Afr. J. Biotecnol., 9: 24742481.

Arora, D.S. and G.J. Kaur, 2007. Antibacterial activity of some Indian medicinal plants. J. Nat. Med., 61:313-317.

Arroyo, M., 2003. Natural antifungal systems for prevention of mould spoilage in bakery products. Cranfield University Applied Mycology Group Institute of BioScience and Technology. Ph.D. thesis. Pp263.

Asadipour, A., Z. Rezaei, S. Saberi-Amoli, Y. Amanzadeh and A. Ghannadi, 2003. Volatile constituents of the aerial parts of Cymbopogon olivieri (Boiss.) Bor. from Iran. J of EO Bearing Plants, 6(1): 51-54.

Bajpai, V.K., A. Sharma and K. H. Baek, 2013. Antibacterial mode of action of Cudrania tricuspidata fruit essential oil, affecting membrane permeability and surface characteristics of food-borne pathogens. Food control 32 (2): 582-590. doi: 10.1016/j.foodcont.2013.01.032

Cleveland, T. E., J. Yu, N. Fedorova, D. Bhatnagar and G.A. Payne, 2009. Potential Aspergillus flavus genomics for applications in biotechnology. Trends Biotechnol., 27:151-157.

Dahiya, P. and S. Purkayastha, 2012. Phytochemical analysis and antibacterial efficacy of dill seed oil against multi-drug resistant clinical isolates. Asian J of Pharm. and Clinical Res. 5(2):62-64.

De Moss, R.D. and R.C. Brad, 1957. Manual of Microbiology Methods. MC Graw Hill Book Company Inc New York 170-171.

Delaquis, P.J., K. Stanich, B. Girard and G. Mazza, 2002. Antimicrobial activity of individual and mixed fractions of dill, cilantro, coriander and eucalyptus essential oils. Int J Food Microbiol., 74(1-2):101-109. https://doi.org/10.1016/S0168-1605(01)00734-6

Difco, manual, 1984. Manual of dehydrated culture media and reagents for microbiology. 9th edition. Difco laboratory. Det roti. Michigan 28232, USA.

Efstration, E., A.I Hussain, P.S Nigam, J.E Moore, M.A. Ayub and J. R. Rao, 2012. Antimicrobial activity of Calendula officinalis petal extracts against fungi, as well as Gram-negative and Grampositive clinical pathogens. Complement Ther Clin Pract., 18(3):173-6. doi: 10.1016/j.ctcp.2012.02.003.

El- Gayyar, M., F. A. Draughon, D. A. Golden and J. R. Mount, 2001. Antimicrobial activity of essential oils from plants against selected pathogenic and saprophytic microorganisms. J of Food Protect. 64(7):1019-24. doi: 10.4315/0362-028x-64.7.1019.

Fung, D.Y.C., S. Taylor and J. Kahan, 1977. Effects of butylated hydroxyanisole (BHA) and butylated hydroxytoluene (BHT) on growth and aflatoxin production of Aspergillus flavus. J. of Food Safety, 1(1): 39-51. Https://doi.org/10.1111/j.1745-4565.1977.tb00258.x

Ghadimipour, R. and S.S. Eteghad, 2015. Inhibitory effects of butylated hydroxyanisole on growth of molds and yeasts at different $\mathrm{pH}$ conditions and different $\mathrm{NaCl}$ concentrations. Jordan Med J 49(3):139-145.

Gomaa, S.E. and R.A. Abdel Rahman, 2013. Datura, From Field to Biotechnology. Lambert Academic Publishing, Germany. Pp95. ISBN 978-3-659-38110-2

Gomaa, E.G., N.M. Ismail, M.Z.M. Salem and S.E. Gomaa, 2016. In vitro Screening for Antimicrobial Activity of Some Medicinal Plant Seed Extracts. Int. J of Biotec. for Wellness Industries, 5 (4): 142-152. Online: https://bit.ly/2vIAkP8. 
Hojjati, M., 2017. Chemical constituents and antibacterial activity of dill (Anethum graveolens) essential oil. ASEAN conference of food science and technology Nov. 14-17, Ho Chi Minh City, Vietnam.

Hussein, A. H., A.A. Said-Al Ahl,, A. M. Sarhan, A.M. Abou Dahab, E.N. Abou-Zeid, M. S. Ali, Nabila Y. Naguib and M.A. El-Bendary, 2015. Essential Oils of Anethum graveolens L.: Chemical Composition and Their Antimicrobial Activities at Vegetative, Flowering and Fruiting Stages of Development. Int J of Plant Sci and Ecol., 1(3): 98-102

Ilhami, G., K. Irafan and O. Munir, 2004. Antioxidant, antimicrobial, antiulcer and analgesic activities of nettle (Urtica dioica L.) J. Elhnopharmacol, 90: 205-215.

Jana, S. and G. S. Shekhawat, 2010. Anethum graveolens: An Indian traditional medicinal herb and spice. Pharmacognosy Reviews, 4 (8): 179-184.

Jirovetz, L., G. Buchbauer, A. S. Stoyanova, E.V. Georgiev and S.T. Damianova (2003). Composition, quality control, and antimicrobial activity of the essential oil of long-time stored dill (Anethum graveolens L.) seeds from Bulgaria. J Agric Food Chem., 51(13):3854-3857.

DOI: $10.1021 / \mathrm{jf030004y}$

Kumar, P., D. K. Mahato, M. Kamle, T. K. Mohanta and S.G. Kang, 2017. Aflatoxins: A Global Concern for Food Safety, Human Health and Their Management. Frontiers in Microbiology www.frontiersin.org. 7:1-10. doi: 10.3389/fmicb.2016.02170

Madugula, P., S. Reddy, J. Koneru, A. Srinivasa Rao, R. Sruthi and D. T. Dalli, 2017. Anifungal Efficacy of Punica Granatum. Journal of Clinical and Diagnostic Research. 11(1):114-117. DOI: 10.7860/JCDR/2017/22810.9304

Mani-López, E., O. C. Zavaleta and A. López-Malo, 2021. A review of the methods used to determine the target site or the mechanism of action of essential oils and their components against fungi. SN Applied Sciences 3:44 doi.org/10.1007/s42452-020-04102-1.

Nada, F.A., H.A. Amra, Sh. R. Mohamed and B.A. Noah Badr, 2018. Effect of dill seeds as anti-fungal properties for bread. Mid East J of App Sci ISSN 2077-4613. 08 (4): 1181-1189.

Najaran, Z. T., M. K.H. Zadeh, M. Nasery and S. A. Emami, 2016. Essential Oils in Food Preservation, Flavor and Safety, Chapter 45 - Dill (Anethum graveolens L.) Oils, Academic press, Pp. 405-412.

Nehdia, I.A., N. Abutahac, H.M. Sbihia, C.P. Tand and S.I. Al-Resayesa, 2020. Chemical composition, oxidative stability and antiproliferative activity of Anethum graveolens (dill) seed hexane extract. GRASAS Y ACEITES 71 (3): 1-9. e374 ISSN-L: 0017-3495.

https://doi.org/10.3989/gya.0455191

Nguyen, L.V.T, N.Q Nguyen, T.N.T An, N.T Van and N.H.T Anh, 2020. Evaluation of polyphenol content and antioxidant activities of Dill leaves extract Anethum graveolens. IOP Conf. Series: Materials Science and Engineering doi:10.1088/1757-899X/991/1/012032

Noah, B.A., F. Nada, M.G. Shehata and H.A. Amra, 2017. Anti-mycotic and Anti-mycotoxigenic Properties of Egyptian Dill. J of App Sci. 17(:4) 184-195. DOI: 10.3923/jas.2017.184.195

Prakash, B., P. Singh, A. Kedia and N.K. Dubey, 2012. Assessment of some essential oils as food preservatives based on antifungal, antiaflatoxin, antioxidant activities and in vivo efficacy in food system. Fd Res Inter 49(1):201-208. DOI: 10.1016/j.foodres.2012.08.020

Raccach, M., 1984. The antimicrobial activity of phenolic antioxidants in foods: A review. J. Food Safety, 6 (3): 141-170.

Razavi-Rohani, S.M. and M. W. Griffiths, 1999. The antifungal activity of butylated hydroxyanizole and lysozyme. J. Food safety, 19 (2): 97-108. Https://doi.org/10.1111/j.1745-4565.1999.tb00237.x

Saad, B., Y.Y. Sing, M.A. Nawi, N. Hashim, A.M. Ali, M.I. Saleh and K. Ahmed, 2007. Determination of synthetic phenolic antioxidants in food items using reversed-phase HPLC. Food Chemistry 105(1):389-394. DOI: 10.1016/j.foodchem.2006.12.025

Said-Al Ahl, H.A.H. and E.A. Omer, 2016. Essential oil content and chemical composition of eight dill (Anethum graveolens L) cultivars cultivated under Egyptian conditions. Int J Pharm Pharm Sci., 8(5): 227-231.

Shahidi, F. and P. Ambigaipalan, 2015. Phenolics and polyphenolics in foods, beverages and spices: Antioxidant activity and health effects, review J of functional fd 18: 820-897. http://dx.doi.org/10.1016/j.jff.2015.06.018. 
Singh, G., S. Maurya, M.P. de Lampasona and C. Catalan, 2006. Chemical Constituents, Antimicrobial Investigations, and Antioxidative Potentials of Anethum graveolens L. Essential Oil and Acetone Extract. J of food Sci., 70, (4):208-215.https://doi.org/10.1111/j.1365-2621.2005.tb07190.x

Singleton, V. L. and J.A. Rossi, 1965. Colorimetry of Total Phenolics with PhosphomolybdicPhosphotungstic Acid Reagents. American J of Enology and Viticulture. 16: 144-158.

Snedecor, G.W and W.G. Cochran, 1980. Statistical Methods. The Iowa State University Press, Ames, USA.

Stanojević, L. P., N.S. Radulovićb, T.M. Djokićc, B. M. Stankovića, D. P. Ilića M.D.Cakića and V.D.Nikolića, 2015. Industrial Crops and Products. 65: 429-436.

Suh, H.J., M.S. Chung, Y.H. Cho, J.W. Kim, D.H. Kim, K.W. Han and C.J. Kim, 2005. Estimated daily intakes of butylated hydroxyanisole (BHA), butylated hydroxytoluene (BHT) and tert-butyl hydroquinone (TBHQ) antioxidants in Korea. Food Addit. Contam., 22 (12):1176-88. PMID: 1635688. DOI: 10.1080/02652030500195288

Swamy, M. K., M. S. Akhtar and U. R. Sinniah, 2016. Antimicrobial Properties of Plant Essential Oils against Human Pathogens and Their Mode of Action: An Updated Review. Evidence-Based Complementary and Alternative Medicine ID 3012462, 21 pages. http://dx.doi.org/10.1155/2016/3012462

Taotao, L., Q. Jian, F. Chen, Y. Wang, L. Gong, X. Duan, B. Yang and Y. Jiang, 2016. Influence of Butylated Hydroxyanisole on the Growth, Hyphal Morphology, and the Biosynthesis of Fumonisins in Fusarium proliferatum. J. of Front. Microbiol., 7: 1038-1045. https://doi.org/10.3389/fmicb.2016.01038

Tian, J., X. Ban, H. Zeng, J. He, Y. Chen and Y. Wang, 2012. The mechanism of antifungal Action of essential oil from Dill (Anethum graveolens L.) on Aspergillus flavus. PLoS ONE, 7 (1): 1-10.

Tongnuanchan, P. and S. Benjakul, 2014. Essential Oils: Extraction, Bioactivities, and Their Uses for Food Preservation. J of Food Sci., 79(7):1231-1249.

Villanueva J. M., M. A.V. Arugay and R. Z. H. Ramos, 2008. In vitro Antimycotic Activity of Four Medicinal Plants Versus Clotrimazole in the Treatment of Otomycosis: A Preliminary Study. Phil $\mathrm{J}$ of otolaryngology-head and neck Surgery, 23(1): 5-8. 